Romuald Jaworski*

Warszawa

\title{
Przebaczenie w psychoterapii
}

Problematyka przebaczenia była przez długi czas nieobecna we współczesnej psychologii. Jeszcze w latach siedemdziesiątych XX wieku traktowano ten temat jako teologiczny lub filozoficzny, lekceważąc znaczące aspekty przeżyć związanych z przebaczaniem. Dopiero gdy w obszarze psychoterapii podjęto kwestie związane z doświadczaniem krzywdy i winy, wyłoniły się pierwsze teorie dotyczące przebaczenia, a także określone strategie i techniki zmierzające do wybaczenia i pojednania. Jerzy Melibruda pisze, że w sytuacji krzywdy życie uczuciowe zostaje zdominowane przez cierpienie. Poczucie krzywdy powstaje wtedy, gdy człowiek doświadcza cierpienia, poczucia bezsilności i burzenia ustalonego porządku określającego ważne aspekty życia. Pojawia się wówczas potrzeba obrony oraz radzenia sobie z bólem. Człowiek zamyka się w sobie. Nie ryzykuje nowych kontaktów. Rezygnuje przez to z rozwoju ${ }^{1}$. Jak można poradzić sobie z dokuczliwą niesprawiedliwością, z poczuciem krzywdy? Zdaniem Joahima Kixa istnieją trzy możliwości reagowania na niesprawiedliwość:

* Ks. dr hab. Romuald Jaworski, prof. UKSW, jest kierownikiem Katedry Psychologii Religii w Instytucie Psychologii Uniwersytetu Kardynała Stefana Wyszyńskiego w Warszawie. Adres: Instytut Psychologii UKSW, ul. Wóycickiego 1/3, bud. 14, 01-938 Warszawa; e-mail: romualdjaworski@wp.pl.

1 Jerzy Mellibruda, „Pułapka nieprzebaczonej krzywdy w aspekcie psychologicznym”, w: Krzywda i przebaczenie, red. Tadeusz Huk, Anna Foltańska (Kraków: Wydawnictwo M, 1997), 9-38. 
1. Zrewanżować się, „oddać pięknym za nadobne”, wyznaczyć krzywdzicielowi granice i odreagować się na nim - zareagować grzechem zemsty i odwetu na grzech innego człowieka.

2. „Przełknąć” niesprawiedliwość, ,zrobić dobrą minę do złej gry” - to rozwiązanie przynosi ze sobą wiele problemów; gdy ukryję ból i nie przepracuję go, wtedy wciąż nowe zranienia będą mnie dotykały z coraz większą siłą; zranienie będzie coraz głębsze, chociaż pozornie „wszystko będzie w porządku”; pewnego dnia „naczynie” goryczy zostanie przepełnione i „kropla do pełnej szklanki” wyzwoli całą negatywną energię, czasem ta energia skierowana do wewnątrz ujawni się w skutkach cielesnych, psychosomatycznych.

3. Przebaczyć, to znaczy wytrzymać ból, nie uchylać się przed nim, nie chcieć bronić się samemu i samemu sobie pomóc, lecz złączyć się z Bogiem w tej trudnej sytuacji - ta reakcja jest możliwa tylko wtedy, gdy człowiek ma zaufanie do Boga; z Jego pomocą może przezwyciężyć zło dobrem².

Wielość szkół i podejść psychologicznych jest przyczyną różnic w definiowaniu przebaczenia. Jedni rozumieją je jako akt, inni jako proces. Nurty poznawcze odnoszą akt przebaczenia do sfery intelektualnej i traktują jako proces zrozumienia krzywdy, siebie oraz krzywdziciela. Reprezentanci podejścia psychoanalitycznego czy psychodynamicznego traktują proces przebaczenia w kategoriach przepracowania emocji powstałych na skutek wyrządzonej krzywdy. Także w wymiarze temporalnym, dotyczącym lokalizacji procesu przebaczenia w czasie, występują rozbieżne koncepcje. Jedni są zdania, że należy cofnąć się do czasu i wydarzeń związanych z doznawaniem krzywdy. Inni uważają, iż istotne są aktualne przeżycia, myśli i emocje oraz zachowanie wobec krzywdziciela (koncentracja na tu i teraz). Są wreszcie zwolennicy przekonania, że dla procesu przebaczania kluczowe znaczenie ma antycypowane wyobrażenie czy przeżycie nowych, jakościowo lepszych relacji do samego siebie oraz dotychczasowego krzywdziciela.

$\mathrm{W}$ refleksji nad znaczeniem i miejscem przebaczenia w procesie psychoterapii trzeba pamiętać o tej złożoności zjawiska, a także o różnorodności koncepcji psychologicznych wyjaśniających istotę i specyfikę przebaczenia. Równocześnie warto zauważyć związek przebaczenia z podstawowymi zjawiskami występującymi w psychoterapii, takimi jak: wgląd, opór, przeniesienie i przeciwprzeniesienie, catharsis. W analizie czynników leczących

\footnotetext{
2 Joahim Kix, „Ist es «vergeblich»?“, IGNIS-Journal IX (1994): 20-30.
} 
w psychoterapii warto zobaczyć ich występowanie i znaczenie w procesie przebaczenia.

Tab. 1. Postawy wobec krzywdy

\begin{tabular}{|c|c|c|c|}
\hline & 1. Odreagowanie & 2. Wyparcie & $\begin{array}{l}\text { 3. Konfrontacja } \\
\text { i przebaczenie }\end{array}$ \\
\hline 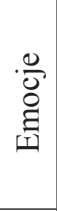 & $\begin{array}{l}\text { złość, wściekłość, } \\
\text { gniew, niekontro- } \\
\text { lowane odreago- } \\
\text { wanie się }\end{array}$ & $\begin{array}{l}\text { wyprzeć wściekłość, wy- } \\
\text { rugować złość i gniew; } \\
\text { te negatywne emocje są } \\
\text { zdaniem wielu chrześci- } \\
\text { jan zabronione i grzeszne }\end{array}$ & $\begin{array}{l}\text { wnikliwie przyjrzeć się winie, } \\
\text { także i swojemu udziałowi; po- } \\
\text { zwolić na ujawnienie się uczuć; } \\
\text { jasno nazwać winę własną i in- } \\
\text { nych; oskarżyć za winę }\end{array}$ \\
\hline 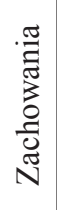 & $\begin{array}{l}\text { brak gotowości do } \\
\text { przebaczenia, od- } \\
\text { danie krzywdą za } \\
\text { krzywdę, przejście } \\
\text { do ofensywy }\end{array}$ & $\begin{array}{l}\text { różne praktyki usprawie- } \\
\text { dliwienia (pomniejszanie } \\
\text { znaczenia, niedocenia- } \\
\text { nie, relatywizowanie, } \\
\text { odraczanie winy) }\end{array}$ & $\begin{array}{l}\text { przebaczenie przez ułaskawienie } \\
\text { pomimo jasno określonej winy; } \\
\text { przebaczenie przyjąć pomimo } \\
\text { popełnionej winy; rezygnacja } \\
\text { z zemsty; Bóg ma być Sędzią }\end{array}$ \\
\hline$\frac{\frac{\vec{v}}{\vec{n}}}{\frac{\vec{n}}{\omega}}$ & $\begin{array}{l}\text { zerwane relacje, } \\
\text { strategia funkcjo- } \\
\text { nuje przez jakiś } \\
\text { czas, „ma się in- } \\
\text { nych w ręku” }\end{array}$ & $\begin{array}{l}\text { wyparcie powoduje } \\
\text { zgorzknienie, niezado- } \\
\text { wolenie, obłudę; relacje } \\
\text { są tylko pozornie po- } \\
\text { prawne }\end{array}$ & $\begin{array}{l}\text { pokój, celem staje się ponowne } \\
\text { pojednanie i poprawne relacje }\end{array}$ \\
\hline
\end{tabular}

Źródło: opracowanie własne.

Przebaczenie jest zarówno doświadczeniem osobistym, jak i interpersonalnym. Dlatego jednym z ważnych aspektów w analizie przebaczenia jest spostrzeganie go jako procesu wewnątrzpsychicznego albo analizowanie go jako relacji międzyosobowej ${ }^{3}$.W tym pierwszym przypadku przebaczenie jest rozumiane jako oczyszczenie krzywdziciela $z$ win, pokonanie negatywnego stosunku do niego. Krzywdziciel nie odgrywa przy tym żadnej aktywnej roli, pozostaje bierny i obojętny wobec przeżyć, jak też działań pokrzywdzonego. Przedstawiciel tego nurtu - Robert Enright, twórca Międzynarodowego Instytutu Przebaczenia (International Forgiveness Institute), określa przebaczenie jako pełen samopoświęcenia dar miłości, który nie potrzebuje wyprzedzającej reakcji drugiej osoby ${ }^{4}$. W drugim przypadku, którego repre-

${ }^{3}$ Avis Clendenen, Martin Troy, Uzdrawiająca siła przebaczania (Kraków: Wydawnictwo WAM, 2004), $29 \mathrm{n}$.

4 Por. tamże, 37. 
zentantami są psycholodzy chrześcijańscy odwołujący się do ewangelicznej strategii przebaczenia, ważnym elementem jest relacja międzyosobowa i dążenie do pojednania. W tym podejściu wymagane jest zaangażowanie zarówno skrzywdzonego, jak i krzywdziciela, a celem jest ich pojednanie.

\section{Przebaczenie jako akt i jako proces}

Przebaczenie jest aktem woli, decyzją dotyczącą relacji i postępowania w stosunku do doznanej krzywdy, a także do krzywdziciela. Jest to akt wyrażający osobiste stanowisko wobec zła, które dotknęło określoną osobę. To stanowisko związane jest z poczuciem własnej tożsamości i godności, a zarazem ze świadomością zaistniałych faktów lub zdarzeń oraz własnej odpowiedzialności za ustosunkowanie się do nich. W takim rozumieniu przebaczenie jest aktem świadomym, wolnym i odpowiedzialnym. Wyraża się w decyzji ustosunkowania do doznanej krzywdy i krzywdziciela. Należy tu uwzględnić różnicę między przebaczeniem jako aktem świadomości a przebaczeniem jako uczuciem ${ }^{5}$.

W kontekście psychoterapii akt przebaczenia wymaga poszanowania wolności i świadomości. Proces psychoterapii jest zatem przygotowaniem do podjęcia decyzji rezygnacji z odwetu, zemsty czy kary. Im wyższy poziom świadomości (wiedzy i zrozumienia krzywdy, a także jej uwarunkowań psychospołecznych i duchowych) i im większy zakres wolności w relacji do krzywdziciela, tym pełniejsze przebaczenie, jak również gotowość do pojednania. Owocem takiego aktu przebaczenia jest odzyskanie wolności, uwolnienie się od ciążących przykrych emocji, poczucie wyższej wartości samego siebie oraz wzrastający szacunek dla ludzi, także tych, którym nie udaje się budowanie dobrych relacji i są sprawcami nieszczęść i bólu innych ludzi.

Dokładniejsza analiza aktu przebaczenia pozwala odkryć i opisać jego dynamiczny charakter. Wyraża się on w specyficznych przeżyciach i charakterystycznym zachowaniu. Przebaczenie jest aktem dynamicznym, procesualnym, w którym można wyróżnić określone fazy czy etapy. Wielu autorów zwraca przy tym uwage na charakterystyczne fazy procesu przebaczenia. Spośród wielu opisów dynamiki procesu przebaczania warto przytoczyć

${ }_{5}^{5}$ Martin H. Padovani, Uleczyć zranione uczucia. Jak przeżywać trudności życiowe (Kraków: Wydawnictwo WAM, 2006), 55 n. 
chociaż kilka. Robert Enright i jego współpracownicy proponują wyróżnienie w przebaczeniu czterech etapów:

1. faza odkrywania - osoba skrzywdzona, będąc świadkiem bólu powstałego w wyniku głębokiego i niesprawiedliwego cierpienia, musi przeanalizować swój ból, uświadomić sobie wywołane przezeń negatywne emocje i próbować je zrozumieć; uzdrawianie zaczyna się, gdy osoba skrzywdzona pozwala bolesnym uczuciom wyjść na światło dzienne;

2. faza decyzji - osoba skrzywdzona, mając świadomość destrukcyjnego trwania w poczuciu krzywdy, podejmuje decyzję o przebaczeniu;

3. faza działania - osoba skrzywdzona próbuje zrozumieć życiowy kontekst, w jakim działał krzywdziciel oraz dostrzec i zrozumieć motywy działania sprawcy; to pomaga $\mathrm{w}$ akceptacji bólu oraz podjęciu decyzji, żeby nie przenosić go na innych, w tym także na sprawcę;

4. faza rozwiązania/pogłębiania - osoba skrzywdzona odczuwa emocjonalną ulgę wypływającą z przebaczenia krzywdzicielowi i doświadcza wewnętrznego uzdrowienia, a w konsekwencji - uczucia wolności 6 .

Dawid Augsburger wymienia sześć kroków w procesie przebaczenia. Każdy z nich jest integralną częścią tego procesu. Wymienione pierwsze trzy kroki nie stanowią jeszcze przebaczenia. Są podstawowym warunkiem do rozpoczęcia pracy nad przebaczeniem. Proces przebaczenia nie może się zakończyć na etapie spełnienia wstępnych warunków, jeśli ważne jest pojednanie i odnowienie związku. A oto kroki przebaczenia według tego autora:

1. przywracanie wartości - ponowne zobaczenie w drugiej osobie wartościowego człowieka, niezależnie od wyrządzonej przez niego krzywdy;

2. miłość - pomimo odczuwanego bólu postrzegania partnera jako drogiej nam osoby;

3. wycofanie żądań dotyczących przeszłości, zdając sobie sprawę, że nie da się zmienić tego, co minęło;

4. zaufanie - wynikające z przeanalizowania gniewu i bólu odczuwanego przez obie strony; dążenie do wzajemnego zaufania; szczerość intencji i skrucha muszą być odczuwane przez obie strony;

${ }^{6}$ Por. Romuald Jaworski, Kiedy miłość boli (Płock: Płocki Instytut Wydawniczy, 2015), 54. 
5. otwarcie się na przyszłość - bez żądania, aby druga osoba dała gwarancje określonego zachowania w przyszłości;

6. świętowanie miłości - odnowienie miłości, troska o to, by głęboki wzajemny kontakt i zdrowe relacje zostały odnowione i odczuwane przez obie strony ${ }^{7}$.

Everett L. Worthington, profesor psychologii na Uniwersytecie w Virginii, pionier badań nad przebaczeniem, opracował pięcioetapowy model przebaczenia:

1. przywołanie krzywdy - w sytuacji, gdy ktoś nas skrzywdzi, najczęściej czujemy złość, strach, smutek i żal; naturalną reakcją na takie zachowanie jest unikanie krzywdziciela oraz unikanie myśli o tych trudnych wydarzeniach; aby sobie z nimi poradzić, należy powrócić do nich i przez wizualizacje krzywdy oraz głęboki i spokojny oddech wyciszyć je;

2. empatia ze sprawcą - aby zrozumieć wydarzenie krzywdy, trzeba spojrzeć na nie z perspektywy sprawcy; jeśli znajdziemy obiektywne wyjaśnienie zachowania krzywdziciela, zrozumiemy motywy jego działania, uwolnimy się od bolesnych wspomnien i będziemy mogli żyć nowym życiem;

3. altruistyczny dar przebaczenia - uznając, że dar przebaczenia jest bardziej potrzebny ofierze niż sprawcy, należy uwolnić krzywdziciela od poczucia winy, a siebie od niepokoju; owocem takiej decyzji będzie radość, zadowolenie, spokój i wolność;

4. zaangażowanie - dobrze jest, by przebaczenie stało się aktem publicznym; to może polegać na wyjawieniu swoich intencji przed osobą lub grupą osób z otoczenia, napisaniu do sprawcy listu z przebaczeniem i głośnym przeczytaniem go lub powiedzeniu komuś zaufanemu o swoim akcie przebaczenia;

5. utrzymanie przebaczenia - myśli związane z krzywdą będą przywoływały bolesne wspomnienia, ale po wybaczeniu nie będą już tak silne i niszczące; kiedy będą się pojawiały, należy na nie nakładać myśli pozytywne, które „zablokują” wywołanie nieprzyjemnych uczuć8.

7 Dawid Augsburger, Sztuka przebaczania, tłum. Andrzej Czarnocki (Warszawa: Świat Książki, 1996), 32.

${ }^{8}$ Everett L. Worthington, „Wybaczalne odpuszczanie”, Charaktery. Magazyn psychologiczny 4 (2010): 17. 
William A. Meninger omawia pięć etapów w procesie przebaczenia: 1) przyjęcie, uznanie faktu zranienia; 2) wina i jej określenie oraz przypisanie sprawcy krzywdy; 3) ofiara; 4) gniew; 5) pełnia9.

Wzorem procesu przebaczenia w ujęciu chrześcijańskim jest Boże przebaczenie ukazane w przypowieści o niemiłosiernym dłużniku (Mt 18, 21-35). Cały wewnętrzny proces przebaczenia obejmuje następujące kroki:

1. decyzja o rozliczeniu się,

2. rozliczenie,

3. ulitowanie się, zmiłowanie,

4. uwolnienie,

5. odpuszczenie winy, darowanie długu ${ }^{10}$.

Proces przebaczenia otwiera na gotowość pojednania, które jest faktycznym pokonaniem rozgoryczenia i przyczynia się do odbudowy oraz rozwoju poprawnych relacji międzyosobowych. W rozbudowanej chrześcijańskiej strategii przebaczenia należy uwzględnić następujące etapy ${ }^{11}$ :

1. prosić Ducha Świętego o pomoc w rozeznaniu, gdzie potrzeba przebaczenia;

2. każdą sytuację związaną z przebaczeniem przemodlić i wyznać własną winę oraz nieprzebaczenie;

3. wyzwolić osobę, która mnie zraniła poprzez wypowiedzenie autentycznego ,przebaczam”;

4. uwolnić się od zgorzknienia poprzez odkrycie w osobie, której przebaczam, tego, co w niej pozytywne;

5. uwolnić siebie z roszczeń i oczekiwań wobec krzywdziciela, zrozumieć słabości tych, którzy nas zranili;

6. podziękować Bogu za tę osobę, która mnie zraniła i uwielbić Boga za Jego miłość do tej osoby;

7. regularnie modlić się za krzywdziciela.

Podsumowując wyżej wymienione etapy procesu przebaczenia, można dokonać ich streszczenia do trzech elementów: bilans - wyrok - amnestia.

9 William A. Meninger, Jak przebaczać (Warszawa: Instytut Wydawniczy PAX, 2003), $57-84$

${ }^{10}$ Kix, ,Ist es”, 20-30.

11 Jaworski, Kiedy, 56. 


\section{Przebaczenie w kontekście szkół psychoterapeutycznych}

Aby właściwie opisać miejsce przebaczenia w procesie psychoterapeutycznym, należy uwzględnić wielość rodzajów psychoterapii. Stanisław Kratochvil mówi o psychoterapii dyrektywnej i niedyrektywnej, o psychoterapii objawowej i przyczynowej, o podtrzymującej i konstrukcyjnej, odkrywającej i zakrywającej, o psychoterapii wglądu i działania, wreszcie o psychoterapii indywidualnej, grupowej i zbiorowej ${ }^{12}$. Każda $\mathrm{z}$ tych psychoterapii ma inny cel, a temat przebaczenia jest w nich obecny w specyficzny sposób albo wcale nie jest obecny.

W ujęciu akademickim i w praktyce spotykamy różne szkoły nurty i strategie psychoterapii, które różnią się między sobą celem i przedmiotem psychoterapii, a także stosowanymi technikami. Najczęściej wymienianymi koncepcjami i szkołami psychoterapii są: psychoanalityczna i psychodynamiczna, obie zorientowane głównie na pracę nad emocjami, zazwyczaj tymi, które miały miejsce w przeszłości, a teraz ciążą i ograniczają dobre funkcjonowanie człowieka. Następnym ważnym nurtem jest terapia behawioralno-poznawcza, która jest zorientowana na zrozumienie siebie i świata oraz nauczenie się nowych pozytywnych i adekwatnych schematów zachowania. W nurcie psychoterapii systemowej spostrzega się człowieka w jego powiązaniach z otoczeniem i oddziaływanie na cały system dla wprowadzenia oczekiwanych zmian. Psychoterapia humanistyczna i egzystencjalna zorientowane są na rozwój osobisty pacjenta i odwołują się do ukrytego w nim potencjału psychicznego.

Poszczególne szkoły psychoterapeutyczne odmiennie formułują cele psychoterapii ${ }^{13}$. W podejściu behawioralnym kładzie się nacisk na ustąpienie objawów sygnalizowanych przez pacjenta, w psychoterapii poznawczej na rekonstrukcję u pacjenta obrazu siebie i otoczenia, w psychoanalizie uwolnienie od ciążących wypartych przeżyć z dzieciństwa. W poszukiwaniu wspólnych kryteriów poprawy pacjenta (skutków psychoterapii) wymienia się najczęściej: ustąpienie objawów, lepsze funkcjonowanie psychiczne - wzrost poczucia komfortu psychicznego, lepsze przystosowanie - efektywność społeczną i samoświadomość.

12 Stanisław Kratochvil, Podstawy psychoterapii (Poznań: Zysk i S-ka: 2003), 20-23.

13 Urszula Jakubowska, „Modele badań nad psychoterapią”, w: Psychoterapia-badania i szkolenia, red. Lidia Grzesiuk (Warszawa: Wydawnictwo Eneteia, 2006), 23. 
Temat przebaczenia nie należy do głównych wątków czy wartości występujących w tych wyżej wymienionych nurtach psychoterapii. Tylko w psychoterapiach bazujących na antropologii chrześcijańskiej temat przebaczenia uzyskuje wysoką rangę i należy do wiodących wątków i strategii pomagania. Dokładniejsza analiza aktu przebaczenia wpisuje się w problematykę celów i strategii psychoterapii. Psychologia ma duży wkład w poznanie samego procesu przebaczenia. Szczególnie wartościowe jest wskazanie źródeł trudności w przebaczaniu oraz ukazanie konsekwencji przebaczenia.

Ogólnie można stwierdzić, że wszystkie szkoły i strategie psychoterapeutyczne zmierzają do zdrowego, normalnego, poprawnego funkcjonowania pacjenta. Często mówi się o zranieniach, które są przedmiotem uwagi, troski i leczenia w procesie psychoterapeutycznym. Człowiek zraniony stawia pytanie o sprawcę oraz przyczynę tego zranienia, a także o możliwe ustosunkowanie ofiary do krzywdziciela. W tym miejscu kwestia przebaczenia okazuje się ważna, a nawet zasadnicza. Celem przebaczenia jest odzyskanie wolności od ciemiężących doświadczeń poczucia krzywdy i poczucia winy. Jest nim także w dalszej kolejności możliwość odzyskania dobrych relacji między poróżnionymi osobami.

Cel psychoterapii można określić jako stan wewnętrznej i zewnętrznej zgodności, harmonii. Także celem przebaczenia jest pokonanie tego, co dzieli i zbudowanie zdrowych relacji. Konflikty wewnętrzne i zewnętrzne zostają przezwyciężone na drodze odbudowywania zaufania do samego siebie, do Boga, do innych ludzi. Tendencja do kontrolowania sytuacji życiowej nie osiąga destrukcyjnego poziomu, a wyraża się w otwartości na prawdę, że w życiu każdego człowieka obecne są aspekty (reakcje, motywacje, zachowania) pozytywne i negatywne. Ich odkrycie i uwzględnianie jest przejawem dojrzałości osoby ludzkiej. To, co dostrzeżone i nazwane, przestaje w ukryty sposób kontrolować i uzależniać życie od zranień, ale może być korygowane, a nawet wykorzystane dla rozwoju w stronę dojrzałości. Przeżyte traumatyczne doświadczenia przestają być zniewalające, nie muszą napawać lękiem ani blokować rozwoju. Lęk zostaje pokonany. Odwaga skonfrontowania się z krzywdą i krzywdzicielem sprawia, że trudne, raniące doświadczenia stanowią ważny element zdobytej mądrości życiowej.

\section{Przebaczenie innym, sobie i Bogu}

W zależności od spostrzeganego źródła krzywdy, bólu lub upokorzenia możemy wyróżnić najczęściej występujących adresatów aktu przebaczenia. 
Są to inni ludzie, nieraz bliscy, a czasem zupełnie nieznani. Często pretensja, a w konsekwencji także przebaczenie, kierowane jest w stronę Boga, spostrzeganego w kategorii Najwyższej Siły, od której zależne były zachowania i zdarzenia. Czasem, gdy człowiek ma świadomość własnego udziału w spowodowaniu doświadczanego cierpienia, wyzwalana jest złość, gniew na samego siebie, a także potrzeba wybaczenia sobie samemu. Funkcjonuje powszechnie przekonanie, że Bóg wybacza nawet najcięższe przewinienia, inni ludzie mogą wybaczyć, ale trudniej jest wybaczyć sobie samemu, natomiast natura nigdy nie wybacza. W powiedzeniu tym ukryte jest przekonanie o nieuchronności kary za popełnione zło. W tym kontekście w psychoanalizie mówi się o mechanizmie restytucji, który stoi na straży sprawiedliwości i konieczności wynagrodzenia za popełnione zło. W przypadku braku kompensaty za zło wyrządzone innym człowiek ulega presji nastawień autodestrukcyjnych zmierzających do wyniszczenia siebie (często aż po samobójstwo) dla odkupienia popełnionych win. Mechanizm restytucji, podobnie jak inne mechanizmy obronne, funkcjonuje - zdaniem psychoanalityków na poziomie nieświadomym. Proces przebaczenia jest świadomy i pomaga przezwyciężyć mechanizm restytucji. Przebaczenie, jako specyficzny akt amnestii, stanowi swoistą opozycję w stosunku do przekonania o sprawiedliwości i nieuchronności kary za popełnione zło.

Gdy człowiek ma poczucie skrzywdzenia przez innych ludzi, to przebaczenie im uzależnia od wielu czynników: wielkości i częstotliwości krzywdy, bliskości i częstotliwości relacji łączących ofiarę i sprawcę (osoby obce i osoby bliskie, z którymi są liczne i intensywne więzi), obecności lub braku skruchy u sprawcy krzywdy, częstotliwości osobistych doświadczeń przebaczania u skrzywdzonego. Warto w procesie psychoterapii zmierzającej do przebaczenia innym uwzględnić te wyżej wymienione okoliczności.

Przebaczenie Bogu uzależnione jest od dojrzałości religijnej osoby skrzywdzonej. Im bardziej prymitywne, uproszczone i zdeformowane obrazy Boga u osób skrzywdzonych, tym trudniejsze przebaczenie Bogu. W takich sytuacjach skrzywdzony ignoruje swoją podmiotowość, spostrzega siebie jako bezgranicznie uzależnionego od Boga, ignoruje swoją własną wolę i oskarża Boga za doznane nieszczęścia. W takim przypadku ważna jest praca w obszarze duchowym nad skorygowaniem obrazu Boga.

Gdy ktoś oskarża siebie za zaistniałe nieszczęście lub doznane zło, musi uporać się nie tylko z poczuciem krzywdy, ale także z poczuciem winy. Balast tych negatywnych emocji może być tak wielki, że prowadzi do zastosowania mechanizmu ucieczki, a czasem autodestrukcji. W terapii takich osób 
trzeba pamiętać, aby leczyć oba te stany. Przy tym krzywdę leczy się poprzez przebaczenie, a winę poprzez przeproszenie i ekspiację.

Mądrość życiowa i miłość Boga stanowią istotny impuls w kierunku osiągania zdrowia i integralnej dojrzałości. Przebaczenie komuś jest związane z przebaczeniem sobie. To jest podstawowa zasada psychoterapeutyczna. Trzeba zaprzestać ustawicznego oskarżania siebie i przebaczyć sobie twierdzi Reinhard Tausch ${ }^{14}$. Temat przebaczenia nie może być oderwany od kontekstu relacji do Boga. Przebaczenie jest czymś więcej niż procesem wewnątrzpsychicznym. Przebaczenie w sensie biblijnym usuwa realną winę, a nie tylko poczucie winy. Przebaczam w pierwszym rzędzie nie dlatego, aby mieć dobre samopoczucie, lecz aby na ziemi spełniona została wola Boża. Dopiero jako konsekwencja przychodzą pokój i pojednanie.

\section{Przebaczenie a proces psychoterapii}

Proces psychoterapii i proces przebaczenia mają wiele wspólnego. Pierwszym etapem i elementem jest odkrycie oraz nazwanie doświadczanych trudności, przykrości, krzywd. Odkrywanie bolesnego miejsca - i nazywanie natury, przyczyn, rodzaju bólu - wiąże się z dyskomfortem, lękiem i innymi przykrymi doświadczeniami. Dlatego wiele osób ukrywa swój ból, swoje zranienia, ponieważ nie chce na nowo przeżywać konfrontacji z tym trudnym doświadczeniem, które było u początku historii przeżywanej choroby psychicznej czy zaburzeń funkcjonowania psychospołecznego.

Zgodnie z dynamiczną koncepcją przeżywania zranień ${ }^{15}$ proces przebaczania i proces psychoterapii przeżytej traumy przebiegają przez te same pięć etapów: zaprzeczenie, gniew, pertraktacje, przygnębienie i afirmację. W zależności od głębokości zranień, wcześniejszych doświadczeń z przebaczaniem, rodzaju uzyskiwanego wsparcia proces ten może przebiegać wolniej lub szybciej. Może dokonać się zatrzymanie (fiksacja) na poszczególnych etapach, mogą też występować odstępstwa od kolejności przeżywanych uczuć.

Przebaczenie może być traktowane jako cel psychoterapii. Akt przebaczenia uwalnia od uzależnienia pokrzywdzonej osoby od bólu krzywdy

${ }^{14}$ Reinhard Tausch, „Verzeihen: die doppelte Wohltat“, Psychologie Heute 4 (1993): $27-35$.

15 Por. Dennis Linn, Matthew Linn, Uzdrawianie ludzkich zranień, tłum. Agata Bożek (Kraków: Wydawnictwo M, 1993). 
i od krzywdziciela. Jednak najgłębszym celem psychoterapii w kontekście przebaczenia jest nabycie umiejętności przebaczania. Chodzi nie tylko o pojedynczy akt ułaskawienia krzywdziciela i uwolnienia się od brzemienia jednorazowej krzywdy, ale o osiągnięcie takiej sprawności, która łączy się ze stałą gotowością do wybaczania. Oczywiście nie chodzi tu o przemilczenie krzywdy, o jej represjonowanie, „zamiatanie pod dywan”, ale o umiejętność wchodzenia $\mathrm{w}$ proces przebaczenia $\mathrm{z}$ wszystkimi jego etapami i elementami. Na tym właśnie polega odbudowanie zranionej krzywdą osobowości. Tę zdolność może osiągnąć tylko ta osoba, która jest w stanie zobaczyć siebie także jako osobę krzywdzącą i doświadczającą przebaczenia. Oczywiście tego typu przeżycie jest o wiele łatwiejsze dla ludzi autentycznie wierzących, uznających fakt, że Bóg im przebaczył i dlatego oni też mogą oraz powinni przebaczyć („Nie mówię ci, że aż siedem razy masz przebaczać, ale aż siedemdziesiąt siedem razy”; „,..odpuść nam nasze winy, jako i my odpuszczamy naszym winowajcom").

W istocie chodzi o wybór stylu życia: albo opartego na przebaczeniu, albo nacechowanego rozgoryczeniem i potrzebą zemsty. Te dwa style życia ilustruje poniższa tabela.

Bracia Dennis i Matthew Linn piszą, że przebaczenie, którego Bóg mi udzielił, oraz moje przebaczenia drugiej osobie mają się do siebie jak głos i echo ${ }^{16}$. Przebaczenie i ułaskawienie mnie ze strony Boga stanowi motyw i wzór dla przebaczenia, którym mam objąć osoby, wspólnoty, środowiska i instytucje, które mnie skrzywdziły. Dopiero dokonany akt przebaczenia uwalnia mnie od ciężaru krzywdy. Umiejętność przebaczania broni człowieka przed destrukcyjnym wchodzeniem w trójkąt dramatyczny: prześladowca - ofiara - obserwator.

Doświadczenie krzywdy uruchamia mechanizmy obronne służące ochronie przed cierpieniem. Funkcjonowanie na poziomie mechanizmów obronnych: wyparcia, racjonalizacji, projekcji, restytucji, przyczynia się do zafałszowania obrazu siebie i świata. Dla przezwyciężenia tych trudności trzeba wejść na drogę przebaczenia. Owocem psychoterapii jest wgląd w siebie, w swoje motywacje, uczucia, uwarunkowania, zniewolenia. Konfrontacja z zadaniem przebaczenia sprawia, że proces samopoznania i samooceny ulega intensyfikacji. Pytanie o gotowość do przebaczenia weryfikuje poziom akceptacji siebie i innych. Człowiek uczy się odróżniać ocenę czynu od oceny sprawcy, osiąga zdolność empatii, jak również rozwija swoją inteligencję emocjonalną, na którą składają się nie tylko lepsze rozumienie swoich sta-

16 Tamże, 27. 
Tab. 2. Style życia

\begin{tabular}{|c|c|}
\hline Styl życia oparty na przebaczeniu & Styl życia nacechowany rozgoryczeniem \\
\hline $\begin{array}{l}\text { Mt 18,21-35 } \\
\text { W przypowieści o niemiłosiernym dłuż- } \\
\text { niku dłużnik chce odzyskać od swego } \\
\text { kolegi własną należność, ale nie ma } \\
\text { przy tym pojęcia, jak wielkie są jeszcze } \\
\text { jego długi. }\end{array}$ & $\begin{array}{l}\text { Hbr } 12,15 \\
\text { Zgorzknienie zniewala, krępuje, zatruwa } \\
\text { nas samych, uniemożliwia Bogu błogosła- } \\
\text { wienie nam i zaraża innych. Gorycz wyra- } \\
\text { sta z nienawiści, z zemsty. }\end{array}$ \\
\hline $\begin{array}{l}\text { Na przebaczenie składają się: } \\
\text { 1. darowanie winy (uwolnienie od } \\
\text { winy), } \\
\text { 2. uwolnienie osoby - rezygnacja z ze- } \\
\text { msty za krzywdę i potraktowanie osoby } \\
\text { tak, jakby nam nic złego nie uczyniła, } \\
\text { 3. ćwiczenie miłosierdzia - nie opowia- } \\
\text { damy dalej nikomu o tym, że ktoś nas } \\
\text { zranił. } \\
\text { Przykazanie miłości: „Miłość wszyst- } \\
\text { kiemu wierzy” (1 Kor } 13,7 \text { ) - Jezus } \\
\text { chce abyśmy z innymi obchodzili się } \\
\text { tak, jak on obchodzi się z każdym } \\
\text { z nas. On nigdy nie wątpi w nas. } \\
\text { Umiejętność objęcia wszystkich i prze- } \\
\text { kazania znaku pokoju pozwala uwol- } \\
\text { nić się od bolesnych wspomnień. }\end{array}$ & $\begin{array}{l}\text { Brak przebaczenia oznacza: } \\
\text { 1. utrzymanie długów, win i dokładną ich } \\
\text { znajomość, } \\
\text { 2. zatrzymanie osoby, wymaganie od niej } \\
\text { uregulowania długów, wynagrodzenia, } \\
\text { pokuty, przeproszenia; duszenie jej, kara- } \\
\text { nie na różne sposoby (milczenie, unikanie, } \\
\text { obojętność). } \\
\text { Wskaźnikami braku przebaczenia są } \\
\text { negatywne mówienie o jakiejś osobie; } \\
\text { ton ostry, twardy, krytyczny, negatywny } \\
\text { i odrzucający, wyrzuty, oskarżenia bezpo- } \\
\text { średnio lub pośrednio. Wszystko w osobie, } \\
\text { która nas skrzywdziła, budzi nasz wstręt. } \\
\text { Często używanymi sformułowaniami są: } \\
\text { „zostaw mnie w spokoju”, ,nie dotykaj } \\
\text { mnie”. }\end{array}$ \\
\hline Biblijna terapia rozgoryczenia & $\begin{array}{l}\text { Fałszywe obchodzenie się ze zgorzknie- } \\
\text { niem }\end{array}$ \\
\hline $\begin{array}{l}\text { Decydujemy się przebaczyć danej } \\
\text { osobie tak, jak Bóg uczynił, gdy za nas } \\
\text { dał swego Syna na śmierć krzyżową, } \\
\text { gdy byliśmy grzesznikami, dłużnikami. } \\
\text { Jest to akt jednostronny, wychodzący } \\
\text { od nas. } \\
\text { Bóg nie chce więcej myśleć o moich } \\
\text { grzechach; tak się ze mną obchodzi, } \\
\text { jakbym nigdy nie zgrzeszył i zachęca } \\
\text { mnie do tego, abym innym przebaczał. } \\
\text { Jeśli naprawdę przebaczymy, zapomni- } \\
\text { my winę innych. }\end{array}$ & $\begin{array}{l}\text { Uleganie złym radom: albo nic z tym nie } \\
\text { robić, „niech trawa to zarośnie”, albo wy- } \\
\text { krzyczeć krzywdę, „puścić parę”. } \\
\text { Zgorzknienie uniemożliwia Bogu przeba- } \\
\text { czenie nam i uzdrowienie nas. Bóg wyco- } \\
\text { fuje wtedy swoje przebaczenie, a właśnie } \\
\text { siły demoniczne mają zgodę na to, aby } \\
\text { nas prześladować. „Przebaczać tak - za- } \\
\text { pomnieć nie” - to fałszywe pokonywanie } \\
\text { rozgoryczenia. }\end{array}$ \\
\hline
\end{tabular}

Źródło: Jaworski, Kiedy, 24-25. 
nów emocjonalnych, ale także wyższa zdolność rozumienia emocji innych ludzi oraz rozumienie działań i motywacji innych osób.

Psychoterapia jest szczególnym spotkaniem ze sobą i innymi ludźmi. Poprzez wgląd w siebie i odbudowywanie własnej wartości człowiek zraniony powoli wychodzi z roli ofiary. Zdolność do transcendencji siebie i przezwyciężenia egocentryzmu sprawia, że istotnej korekcie ulega umiejętność relacji interpersonalnych, przede wszystkim komunikowania własnych przeżyć, zdolność wysłuchiwania drugiej strony, odkrywanie współodpowiedzialności za kształtowanie nowych zdrowych relacji.

Dla osób religijnych znaczącym czynnikiem ułatwiającym proces przebaczenia jest doświadczenie uzyskania przebaczenia ze strony Boga. Osoba taka staje się gotowa przebaczyć krzywdzicielowi, gdy sama doświadczyła, że własnym grzechem zraniła Boga, a dzięki Jego Miłosierdziu uzyskała przebaczenie, odkupienie win i kar. Można zatem powiedzieć, że czynnikiem leczącym jest przebaczająca miłość Boga, która staje się impulsem do udzielenia przebaczenia ludziom, gdy zawinili wobec nas. A zatem im silniejsza i zdrowsza jest relacja z Bogiem, tym większa zdolność do przebaczenia, a w konsekwencji do uzyskania wolności wewnętrznej i zdrowia psychiczno-duchowego.

$\mathrm{W}$ procesie psychoterapii, $\mathrm{w}$ którym przebaczenie staje się istotnym elementem, ujawniają się dwie ważne uzupełniające się rzeczywistości: autonomia i komunia. Następuje tu odkrycie własnej autonomii, niezależności, wolności w stosunku do krępującego wcześniej poczucia krzywdy. Ukazuje się też niejednokrotnie szansa na zbudowanie nowej, zdrowej relacji między osobami.

Proces przebaczenia nie przebiega bezproblemowo. Jak w każdej psychoterapii, także i tutaj ujawnia się opór. Wśród przeszkód utrudniających przebaczenie na szczególną uwagę zasługuje poczucie zagrożenia, wynikające z możliwości powtórnego czy kolejnego zranienia. Również przekonanie, że brak przebaczenia zbuduje bariery obronne wokół człowieka zranionego. Źródłami oporu mogą być także: niechęć zapomnienia, brak emocjonalnej siły, by powiedzieć: przebaczam, zwyczajny gniew na krzywdziciela, użalanie się nad sobą (budowanie własnej tożsamości wokół użalania się nad sobą). Zachowywanie pozycji strony skrzywdzonej może dawać fałszywe poczucie sprawiedliwości i wyższości. Annalisa Giulianini zwraca uwagą na trudności w udzielaniu i otrzymywaniu przebaczenia innym ludziom, Bogu i sobie samemu ${ }^{17}$. U wielu osób występują głęboko chowane urazy, pragnie-

${ }^{17}$ Annalisa Giulianini, O przebaczeniu, czyli jak uleczyć duszę. Psychologiczne i duchowe 
nie zadania cierpienia sprawcy krzywdy, skryte przekonania, że sprawca nie zasługuje na przebaczenie, bo i tak się nie zmieni. Dlatego uznają konieczność zemsty ${ }^{18}$.

Istnieją również okoliczności czy zasoby ułatwiające przebaczenie w procesie psychoterapii. Do takich można zaliczyć: pozytywny przykład rodziców, doświadczenie pozytywnych skutków przebaczenia, kontakty i rozmowy w grupach lub z ,nieosądzającymi” osobami, etyczne przesłanie Jezusa lub innych postaci religijnych, zdrowy styl życia, higiena psychiczna, wysoki poziom życia duchowego lub religijnego ${ }^{19}$. Przebaczenie występuje jako wynik mądrości i miłości (dwa czynniki terapeutyczne).

\section{Przebaczenie z perspektywy psychoterapii i duchowości}

Przebaczenie jest doświadczeniem zarówno natury psychicznej, jak i duchowej. Przynosi wiele pozytywnych konsekwencji, a na pierwszym miejscu psychiczny i duchowy rozwój człowieka. Akt i proces przebaczenia wiążą się z zaangażowaniem sfery intelektualnej, emocjonalnej, motywacyjnej, decyzyjnej. Dlatego tak ważne w dążeniu do przebaczenia jest osiągnięcie wglądu w siebie, zrozumienie uwarunkowań, jakim podlega pacjent $\mathrm{i}$ jego otoczenie (w tym również sprawca krzywdy). W procesie psychoterapeutycznym w relacji z terapeutą osoba wybaczająca ma okazję doświadczyć akceptacji i konfrontacji. Uruchamiają się charakterystyczne dla psychoterapii mechanizmy przeniesienia i przeciwprzeniesienia. Mechanizm przeniesienia wiąże się z rzutowaniem na psychoterapeutę uczuć i emocji przeżywanych przez pacjenta wobec sprawcy krzywdy. Klimat gabinetu psychoterapeutycznego zazwyczaj sprzyja zaufaniu i odwadze, by te zalegające negatywne emocje wypowiedzieć i wyrazić, a przez to poddać pod kontrolę, zapanować nad nimi. Przeciwprzeniesienie to zjawisko występowania i ujawniania uczuć psychoterapeuty wobec pacjenta. Jeśli są to uczucia akceptacji, życzliwości, cierpliwości, wtedy łatwiej osobie skrzywdzonej zauważyć także pozytywne aspekty w postawie krzywdziciela.

sprzeczności, tłum. Magdalena Osocha (Kraków: Bratni Zew Wydawnictwo Franciszkanów, 2008), 99-134.

${ }^{18}$ Por. także Godfried Danneels, Przebaczać. Wysitek człowieka, dar Boga (Kielce: Jedność, 2007).

${ }^{19}$ Tausch, ,Verzeihen“, 27-35. 
Świadomość dobrych skutków przebaczenia jest czynnikiem motywującym w kierunku przełamania poczucia krzywdy (rozgoryczenia) i do budowania na drodze psychoterapii nowych zdrowych relacji międzyludzkich. Motywacja ta jest zarówno negatywna (dostrzeganie fatalnych skutków braku przebaczenia), jak i pozytywna (dostrzeganie błogosławionych owoców przebaczenia). Istotne znaczenie ma tu także duchowość i otwarcie na realizowanie polecenia Bożego dotyczącego konieczności przebaczenia. W kontekście religijnym zasadniczym motywem przebaczenia staje się fakt, że przebacza nam Bóg, który jest Bogiem pokoju. Boże przebaczenie wyzwala w ludziach gotowość do przebaczenia. Bóg tego chce, abyśmy do Niego byli podobni (Mt 18, 33), ponieważ On chce nam przebaczyć.

Nieprzebaczanie ze strony człowieka uniemożliwia przebaczenie ze strony Boga. Jeśli nie przebaczymy, lekceważymy ofiarę Jezusa. Niewybaczenie jest grzechem, uzależnia i powoduje rozgoryczenie, a relacje międzyludzkie pozostają obciążone i niemożliwy jest prawdziwy pokój. Kto przebacza, spostrzega świat i rzeczy w innym świetle. Dzięki przebaczeniu można znowu zobaczyć otoczenie z nowej, lepszej perspektywy. Zostaje przezwyciężona przepaść między „,sprawcą” i „ofiarą”. Można z innymi spotkać się bez uprzedzeń, na tym samym poziomie.

Przebaczenie jest niezbędne w każdym wartościowym związku, zajmuje centralne miejsce $\mathrm{w}$ duchowości wielkich religii, zwłaszcza religii chrześcijańskiej. Bez niego nie ma chrześcijańskiego życia i rozwoju. Chrześcijanie motywowani Bożym przebaczeniem dostrzegają jego głębię dzięki tajemnicy Krzyża Jezusa. Omawiając temat przebaczenia w psychoterapii, nie wolno ignorować ani psychologii, ani teologii. Jest to bowiem temat z pogranicza życia psychicznego i duchowego człowieka. „Psychologia i religia powinny się nawzajem stymulować" - pisze Martin H. Padovani ${ }^{20}$. Prawdę o psychicznym i duchowym kontekście przebaczenia w psychoterapii oddaje chyba dobrze tytuł książki kard. Gotfrieda Danneelsa: Przebaczać - wysiłek czlowieka, dar Boga.

\section{Forgiveness in Psychotherapy (Summary)}

To accurately describe the place of forgiveness in the psychotherapeutic process, one should take into account numerous types of psychotherapy. Many trends and schools of psychotherapy exclude forgiveness. But in reality, the process of

${ }^{20}$ Martin H. Padovani, Uleczyć, 29. 
psychotherapy and the process of forgiveness have a lot in common. Discomfort, anxiety and other unpleasant experiences accompany the process of psychotherapy, which reveals personal injuries and painful areas. In forgiveness-oriented therapy one should consider the context of grievance (sometimes also the context of guilt), the situation of the wronged person and his/her mental and spiritual dispositions. Discovering and naming the difficulties experienced, tribulations and grievances is the first stage and element of the process. Since forgiving is not only a mere act but also a process, thus one has to account for its certain phases. The motivation to forgive and the addressee, which is the evildoer, are also of utmost importance. The persons wronged direct their thinking concerning grievances and forgiveness not only toward individuals but also toward God and themselves. Forgiveness gains depth, motivation and efficacy in the context of religion. For Christians, the experience of God's forgiveness becomes the main motive to forgive. Religion becomes a meaningful factor in effective forgiveness-oriented therapy.

Key words: psychotherapy of mental health harm; dynamics of forgiveness; forgiveness in psychotherapy.

\section{Przebaczenie w psychoterapii (Streszczenie)}

Aby właściwie opisać miejsce przebaczenia w procesie psychoterapeutycznym, należy uwzględnić wielość rodzajów psychoterapii. W licznych nurtach i szkołach psychoterapii przebaczenie jest pomijane. Jednak w rzeczywistości proces psychoterapii i proces przebaczenia mają wiele wspólnego. Odkrywanie w psychoterapii osobistych zranień, bolesnego miejsca wiąże się z dyskomfortem, lękiem i innymi przykrymi doświadczeniami. W terapii zorientowanej na przebaczenie należy uwzględnić kontekst krzywdy (z czasem także kontekst winy), kondycję osoby zranionej, jej dyspozycje psychiczne i duchowe. Pierwszym etapem i elementem jest odkrycie i nazwanie przeżywanych trudności, przykrości, krzywd. Ponieważ przebaczenie jest nie tylko aktem, ale także procesem, trzeba uwzględnić fazy tego procesu. Istotne znaczenie ma również motywacja przebaczenia i adresat przebaczenia, czyli krzywdziciel. Osoby skrzywdzone ukierunkowują swoje myślenie dotyczące krzywdy i przebaczenia nie tylko na ludzi, którzy ich skrzywdzili, ale także na Boga i samego siebie. Przebaczenie uzyskuje swoją głębię, motywację i skuteczność w kontekście religii. Dla chrześcijan głównym motywem przebaczenia jest doświadczane przez nich wybaczenie ze strony Boga. Religia jest tu znaczącym czynnikiem skuteczności psychoterapii zorientowanej na przebaczenie. 
Slowa kluczowe: psychoterapia zranień; dynamika przebaczania; przebaczenie w psychoterapii.

\section{Bibliografia}

Augsburger, Dawid. Sztuka przebaczania, thum. Andrzej Czarnocki. Warszawa: Świat Książki, 1996.

Augustyn, Józef. Ból krzywdy, radość przebaczenia. Kraków: Wydawnictwo M, 1998.

Clendenen, Avis, Martin Troy. Uzdrawiająca siła przebaczania. Kraków: Wydawnictwo WAM, 2004.

Cook, Jerry, Stanley C. Baldwin. Miłość, akceptacja i przebaczenie. Warszawa: Warszawskie Seminarium Teologiczne, 1996.

Czabała, Jan Cz. Czynniki leczace w psychoterapii. Warszawa: Wydawnictwo Naukowe PWN, 2006.

Danneels, Godfried. Przebaczać. Wysitek człowieka, dar Boga. Kielce: Jedność, 2007.

Giulianini, Annalisa. O przebaczeniu, czyli jak uleczyć duszę. Psychologiczne i duchowe sprzeczności, thum. Magdalena Osocha. Kraków: Bratni Zew Wydawnictwo Franciszkanów, 2008.

Ide, Pascal. Czy możliwe jest przebaczenie?, tłum. Małgorzata Zaręba. Kraków: Wydawnictwo WAM, 2000.

Jakubowska, Urszula. „Modele badań nad psychoterapią”. W: Psychoterapia - badania i szkolenia, red. Lidia Grzesiuk, 21-44. Warszawa: Wydawnictwo Eneteia, 2006.

Jaworski, Romuald. „Przebaczenie jako psychologiczna strategia radzenia sobie z poczuciem krzywdy". Edukacja Dorostych 3 (2000): 35-46.

Jaworski, Romuald. Kiedy miłość boli. Płock: Płocki Instytut Wydawniczy, 2015.

Kix, Joahim. „Ist es «vergeblich»?“. IGNIS-Journal IX (1994): 20-30.

Kratochvil, Stanisław. Podstawy psychoterapii. Poznań: Zysk i S-ka: 2003.

Larsen, Ernie. Od gniewu do przebaczenia, thum. Ewa Zaremba. Gdańsk: GWP, 2000.

Linn, Dennis Matthew Linn. Uzdrawianie ludzkich zranień, tłum. Agata Bożek. Kraków: Wydawnictwo M, 1993.

Mellibruda, Jerzy. „Pułapka nieprzebaczonej krzywdy w aspekcie psychologicznym". W: Krzywda i przebaczenie, red. Tadeusz Huk, Anna Foltańska, 9-38. Kraków: Wydawnictwo M, 1997.

Mellibruda, Jerzy. Nieprzebaczona krzywda. Warszawa: Instytut Psychologii Zdrowia i Trzeźwości, 1992. 
Meninger, William A. Jak przebaczać. Warszawa: Instytut Wydawniczy PAX, 2003. Monbourquette, Jean. Jak przebaczać? Droga poprzez dwanaście etapów przebaczenia. Kraków: Wydawnictwo M, 1996.

Nieder, John, Thomas M. Thompson. Przebacz i pokochaj na nowo. Warszawa: Vocatio, 1995.

Padovani, Martin H. Uleczyć zranione uczucia. Jak przeżywać trudności życiowe. Kraków: Wydawnictwo WAM, 2006.

Sommet, Jacques. Ludzkie cierpienie i Boże przebaczenie, thum. Janina Anna Żelechowska. Kraków: WAM, 1997.

Tausch, Reinhard. „Verzeihen: die doppelte Wohltat“. Psychologie Heute 4 (1993): 27-35.

Worthington, Everett L. „Wybaczalne odpuszczanie”. Charaktery. Magazyn psychologiczny 4 (2010): 17. 
